\title{
Anal Necrotic Lesion
}

National Cancer Institute

\section{Source}

National Cancer Institute. Anal Necrotic Lesion. NCI Thesaurus. Code C78171.

A necrotic process involving the area of the anus. 